\title{
Protein turnover of breast muscle in germ-free and conventional chicks
}

\author{
By T. MURAMATSU*, D. N. SALTER AND M. E. COATES $\dagger$ \\ National Institute for Research in Dairying, Shinfield, Reading RG2 $9 A T$
}

(Received 14 August 1984 - Accepted 28 January 1985)

1. The effect of the gut microflora on protein turnover in pectoral muscle $(M$. pectoralis profundus) was studied by means of dietary infusion of $\mathrm{L}-\left[\mathrm{U}-{ }^{14} \mathrm{C}\right]$ phenylalanine and of massive dose injection of $\mathrm{L}-\left[4-{ }^{3} \mathrm{H}\right]$ phenylalanine in chicks fed on a semi-purified casein-gelatin (SCG) diet until $19 \mathrm{~d}$ of age, and in those subsequently given either a nitrogen-free (NF) diet or NF supplemented with methionine and arginine (MA) for a further $9 \mathrm{~d}$.

2. Time-course changes in radioactivity released in expired carbon dioxide during the $8 \mathrm{~h}$ infusion period showed that isotopic equilibrium was reached in $4 \mathrm{~h}$ with the SCG diet and in $5 \mathrm{~h}$ with the MA diet. However, with the protein-deprived chicks given the NF diet, isotopic equilibrium was not achieved since radioactivity in $\mathrm{CO}_{2}$ increased linearly throughout.

3. On feeding the NF diet, fractional protein synthesis rate and the absolute amount of protein synthesized in chick breast muscle were reduced. These reductions were partially alleviated by supplementing the NF diet with methionine and arginine.

4. The fractional degradation rate of breast muscle was increased in chicks given the NF diet, while the absolute amount of protein degraded was decreased. The addition of methionine and arginine counteracted these changes brought about by protein starvation.

5. Generally speaking, the presence of the gut microflora had little, if any, effect on protein turnover rate in chick-breast muscle.

It was previously found that protein synthesis in jejunal mucosa and liver of germ-free (GF) chicks was lower, though not significantly, than in corresponding tissues of conventional (CV) controls, irrespective of nutritional status (Muramatsu et al. 1983). The suggested explanation was that in the jejunum the presence of micro-organisms results in increased turnover of epithelial cells (Rolls et al. 1978) and in the liver of CV birds there is greater activity due to the need to metabolize bacterial end-products. Skeletal muscle is not in close association with micro-organisms, so it seemed important to the better understanding of host-microflora interrelations to investigate whether or not the presence of the gut microflora affects muscle protein turnover.

Together with the gastrointestinal tract and liver, muscle is a major contributor to whole-body protein turnover, not only because it comprises about $40 \%$ of body mass (Fowler, 1980) and hence is the largest protein reserve in the body, but also because it is a metabolically active tissue with respect to degrading branched-chain amino acids and synthesizing some dispensable amino acids (Featherston \& Horn, 1973; Goldberg \& Chang, 1978). Indeed in rats and pigs, muscle protein synthesis accounts for 19 and $42 \%$ of the total respectively (Garlick et al. 1975, 1976).

Skeletal muscle protein is likely to be a good indicator of treatment effects since it is sensitive to the shift of nutritional and hormonal status in terms of the magnitude and probably the speed of changes in synthesis and breakdown rates (Millward \& Waterlow, 1978). Only a $1 \mathrm{~h}$ refeeding period, for example, was needed to attain a remarkable increase of muscle protein synthesis in starved-rats (Garlick et al. 1983).

The study now reported was done to examine the effect of the gut microflora on protein

Present addresses: * Laboratory of Animal Nutrition, Faculty of Agriculture, Nagoya University, Chikusa-ku, Nagoya 464, Japan. $\uparrow$ Robens Institute of Industrial and Environmental Health and Safety, University of Surrey, Guildford, Surrey GU2 5XH. 
synthesis in pectoral muscle in chicks given a semi-purified casein-gelatin (SCG) diet, and in those subsequently given a nitrogen-free (NF) diet or NF supplemented with methionine and arginine (MA). Protein turnover was measured by two methods, a dietary-infusion method (Maruyama et al. 1978) and a large-dose injection method (Garlick et al. 1980).

\section{MATERIALS AND METHODS}

Altogether, three experiments were conducted. The first two experiments, with dietaryinfusion and large-dose injection techniques, were done at the National Institute for Research in Dairying, Shinfield, Reading, while the last one, also by the large-dose injection technique, was carried out at Nagoya University, Chikusa-ku, Nagoya, Japan, and, unless stated otherwise, essentially similar procedures to those in the first two experiments were followed.

In the first two experiments, GF chicks of the Rhode Island Red $\times$ Light Sussex cross were used and reared in large Gustafsson stainless-steel isolators as described by Coates et al. (1963). CV birds from the same hatch of eggs were kept in a clean but not sterile room where the physical environment could be maintained to match that present within the isolators. Birds from each environment were reared in stainless-steel cages with mesh floors, and males and females were used evenly among the experimental groups. The continued microbial sterility of the birds within isolators was checked at intervals (Fuller, 1968).

In the last experiment, single-comb White Leghorn chicks were used; no attempt was made to identify the sexes of these birds since it is impossible to distinguish them by the feather colour. They were accommodated in flexible-film isolators (Model CV-1003; CLEA Japan Inc., Tokyo 153, Japan) and reared in metabolism cages with wire-mesh floors as in the first two experiments.

The compositions of the SCG, NF and MA diets have been previously described (Muramatsu et al. 1983). In all experiments, the diets and water were given ad lib. For the dietary-infusion method (Expt 1), an agar-gel diet was prepared by suspending one part of powdered diet in two parts of a warm agar-gel solution, made by dissolving $20 \mathrm{~g}$ agar in 1 litre boiling water. For $4 \mathrm{~d}$ before the infusion of radioisotope, the diets were given in agar-gel form in order to achieve slow and constant passage of the feed along the gut, and hence keep the dietary infusion of the radioisotope as constant as possible. It was confirmed in a preliminary experiment that the change of diet form did not affect the growth rate of the birds.

\section{Experimental procedure}

Expt. 1. Dietary-infusion experiment. The method was based on that of Maruyama et al. (1978) with some modifications. The duration of radioisotope infusion was increased to $8 \mathrm{~h}$, whereas in the study of Maruyama et al. (1978) a $6 \mathrm{~h}$ infusion was used.

The birds were maintained in both environments on the SCG diet until $14 \mathrm{~d}$ of age, and thereafter the same diet was given in agar-gel form. The chicks were reared individually until $1 \mathrm{~d}$ before the measurement, then transferred to metabolism cages that were placed in bags made from a tube of autoclavable flexible plastic film.

On day 18 the birds were fasted overnight for $16 \mathrm{~h}$. The following morning they were offered the SCG agar-gel diet, which contained $25 \mathrm{~g} \mathrm{SCG}, 4 \mu \mathrm{Ci}$ L-[U- $\left.{ }^{14} \mathrm{C}\right]$ phenylalanine (specific radioactivity $521 \mathrm{mCi} / \mathrm{mmol}$; Amersham International plc, Amersham, Bucks) and $6 \mu \mathrm{mol}$ unlabelled phenylalanine as a carrier, for $8 \mathrm{~h}$. During this period, hourly collections of expired carbon dioxide were made so that the time-course change of the released radioactivity could be monitored. At the end of the $8 \mathrm{~h}$ period, the birds were killed by breaking the neck and immediately thereafter the entire breast muscle $(M$. pectoralis 
profundus) was quickly removed and frozen in liquid $\mathrm{N}_{2}$ after discarding the tendon, and then stored at $-20^{\circ}$ until analysis. The remaining birds were given either the NF or MA diet in each environment for a further $9 \mathrm{~d}$, in agar-gel form on the last $4 \mathrm{~d}$. On day 28 the same dietary-infusion procedure with $4 \mu \mathrm{Ci}$ of the labelled phenylalanine was done, except that the amount of the powdered diet was reduced to $15 \mathrm{~g}$ because the protein-depleted chicks had lost their appetite and could not eat as much as those given the SCG diet. Muscle samples were taken for the measurement of protein synthesis. This experiment was repeated once and the values were combined.

The expired $\mathrm{CO}_{2}$ collection was made hourly until the end of the infusion and $\mathrm{CO}_{2}$ was trapped in $15 \mathrm{ml}$ ethanolamine solution. The radioactivity was measured on a $2 \mathrm{ml}$ portion of trapping solution with $10 \mathrm{ml}$ toluene scintillator (Packard Instrument Ltd, Caversham, Berks) and $7 \mathrm{ml}$ methanol. Methanol was added to avoid separation of the sample solution from the scintillator and to obtain a clear mixture. This treatment had little effect on the counting efficiency.

Muscle samples of approximately $1 \mathrm{~g}$ were homogenized with $5 \mathrm{vol}$. ice-cold trichloroacetic acid (TCA) (100 g/l). The precipitate was collected by centrifugation at $1800 \mathrm{~g}$ for $10 \mathrm{~min}$ and washed twice with 1 vol. TCA solution. The supernatant fraction was combined and its radioactivity measured on a Packard Tri-Carb liquid scintillation spectrophotometer for $10 \mathrm{~min}$ or until 5000 counts were accumulated. The radioactivity of free phenylalanine proved to be too low for accurate determination by the method of Garlick et al. (1980) and the less specific method of McCaman \& Robins (1962) was used. The protein precipitate was further washed twice with $5 \mathrm{ml}$ perchloric acid solution $(20 \mathrm{~g} / \mathrm{l})$, then suspended in $10 \mathrm{ml}$ $0.3 \mathrm{M}$-sodium hydroxide and incubated at $37^{\circ}$ until dissolved. Thereafter, $2 \mathrm{ml} \mathrm{HClO}_{4}$ solution $(200 \mathrm{~g} / \mathrm{l})$ was added to reprecipitate the protein, which was hydrolysed in $10 \mathrm{vol}$. $6 \mathrm{~m}$-hydrochloric acid at $100^{\circ}$ for $24 \mathrm{~h}$ in sealed vessels, then evaporated to dryness and dissolved in $0.3 \mathrm{M}$-succinate buffer at $\mathrm{pH} 5.8$. The phenylalanine content and radioactivity in protein-bound samples were determined as described for the supernatant fraction.

Tissue composition was determined by the procedure of Lowry et al. (1951) for protein, a modified Schmidt-Thannhauser method for RNA as described by Munro \& Fleck (1969) and the diphenylamine method as modified by Giles \& Myers (1965) for DNA.

The proportion of the label that was absorbed during the $8 \mathrm{~h}$ period was determined by subtracting the amount of radioactivity recovered in the gastrointestinal contents, spilled or uneaten food, excreta and washings of the cage from the amount administered in the diet. The gastrointestinal contents were collected by washing with saline $(8.5 \mathrm{~g}$ sodium chloride/1) and then combined and homogenized with uneaten food, excreta and washings of the cage. The homogenates of $0.5 \mathrm{ml}$ portions were solubilized in $3 \mathrm{ml} 1 \mathrm{M}$-hyamine hydroxide solution in methanol (Nuclear Enterprises Ltd, Sighthill, Edinburgh) by incubation at $37^{\circ}$ and portions of the mixture were counted for radioactivity after the addition of $10 \mathrm{ml}$ Instagel (Packard Instruments Ltd).

An approximate estimate of the fractional synthesis rate (FSR) of muscle protein in Expt 1 was calculated using the equation described by Garlick et al. (1973) as follows:

$$
S_{b} / S_{i}=\frac{R}{R-1} \times \frac{1-\exp \left(-K_{s} t\right)}{1-\exp \left(-R K_{s} t\right)}-\frac{1}{R-1},
$$

where $S_{b}$ and $S_{i}$ are the specific radioactivities of protein-bound and intracellular free phenylalanine respectively, $R$ is the relative pool size of protein-bound to free phenylalanine and $t$ is time. The equation was solved on $K_{s}$, i.e. the FSR, by a repeated-iteration procedure. However, because the method of assay of $\left[{ }^{14} \mathrm{C}\right]$ phenylalanine was not specific and the compound was uniformly labelled, the values $S_{b}$ and $S_{i}$ may have been overestimated due to the inclusion of $\left[{ }^{14} \mathrm{C}\right]$ tyrosine and other labelled compounds, and values for FSR must 
be taken only as a rough indication. A more accurate measure of protein synthesis was possible in Expts 2 and 3 in which $\mathrm{L}-\left[4^{-3} \mathrm{H}\right]$ phenylalanine was used, and measured in protein and free amino acid fractions by a specific enzyme method.

Expts 2 and 3. Large-dose injection experiments. In Expt 2, the birds were maintained in both environments on the SCG diet until $18 \mathrm{~d}$ of age, and then were fasted overnight. The next morning they were allowed to eat for more than $2 \mathrm{~h}$ and twelve to sixteen birds in each environment were taken for measurement of protein turnover rate. The remaining birds in each environment were given the NF diet for $9 \mathrm{~d}$. Protein turnover rate was measured on day 28 , after the same fasting and re-feeding procedure on twelve and fourteen birds.

In Expt 3, the birds in each environment were maintained on the SCG diet until day 19 , and thereafter they were given either the NF or MA diet for $9 \mathrm{~d}$. On day 28, protein turnover rate was determined similarly in six to eleven birds.

The method for measuring protein synthesis rate was based on that of Garlick et al. (1980), and depends on the measurement of radioactivity in free and protein-bound phenylalanine of tissues after injection of a massive dose of labelled phenylalanine. Radioactive L[4- $\left.{ }^{3} \mathrm{H}\right]$ phenylalanine $(23 \cdot 5 \mathrm{Ci} / \mathrm{mmol}$; Amersham International plc) was combined with unlabelled L-phenylalanine to give $40 \mu \mathrm{Ci}$ and $100 \mu \mathrm{mol} / \mathrm{ml}$ saline $(8.5 \mathrm{~g} \mathrm{NaCl} / \mathrm{l})$, and injected into a wing vein at a dose of $10 \mathrm{ml} / \mathrm{kg}$ body-weight. At 2 and $10 \mathrm{~min}$ after the injection the birds were killed by dislocation of the neck, and the entire breast muscle, $M$. pectoralis profundus, was quickly removed, weighed after removing the tendon, frozen in liquid $\mathrm{N}_{2}$, and then stored at $-20^{\circ}$ until analysis. The FSR of protein was calculated using the formula described by McNurlan et al. (1979). The time taken from killing the bird to freezing the tissue was approximately $60 \mathrm{~s}$ and allowance was made for this in the calculation.

For the estimation of fractional degradation rate (FDR), it was necessary to measure fractional growth rate (FGR) of muscle protein at the time the FDR was determined. This was done by taking muscle samples from the comparably treated birds $3 \mathrm{~d}$ before and $3 \mathrm{~d}$ after the day the isotope was administered, and the regression of muscle protein (mg) $v$. time (d) was calculated from these values and those from the birds given the isotope injection. The FGR was then derived from the daily change in amounts of muscle protein divided by the amount of protein present at that time. The FDR was calculated by the following equation:

$$
F D R=F S R-F G R .
$$

Muscle samples from the left side of the body were used for the determination of phenylalanine content and its radioactivity to give the specific radioactivity of intracellular free and protein-bound phenylalanine according to the method of Garlick et al. (1980).

The muscle samples from the right side of the body were used to measure the tissue composition which was determined by the same procedures as those described in the preceding section of the dietary-infusion experiment.

\section{Statistical treatment}

Analysis of variance was done to assess the significance of the main effects of environment and diet, and the interactions. In Expt. 1, the variance due to the interaction of between experiment $\times$ treatment (i.e. environment, diet, sex, two-way interactions and a three-way interaction) was used as the residual term from which standard errors of differences of means were calculated. In Expts 2 and 3, standard errors of differences of means were calculated from the variance due to replications, and were used to test the significance of differences between means. For some data sets, natural logarithmic transformation was done before the analysis in order to stabilize variances. 


\section{RESULTS}

\section{Expt 1. Dietary-infusion experiment}

The body-weights of the GF and CV birds are given in Table 1, and show a significant reduction after feeding the NF diet $(P<0.05)$. This reduction was significantly alleviated by supplementing the NF diet with methionine and arginine $(P<0.05)$, and no environmental effect nor interaction of environment $x$ diet was seen.

Table 1 also gives the values for pectoral muscle wet weight, and the contents of protein, RNA and DNA. No environmental effect was found in any of these measurements. The muscle weight and protein content were reduced by feeding the NF diet $(P<0.05)$, and the reduction was significantly, though not completely, offset by supplementing the NF diet with methionine and arginine $(P<0.05)$. Muscle RNA content was significantly higher in the SCG group than the rest $(P<0 \cdot 01)$. The breast muscle DNA content was not significantly changed by the dietary treatments nor by the environments.

The ratios, muscle RNA: protein, protein: DNA and RNA: DNA are given in Table 2. No significant environmental difference was found in these ratios. There was little effect of diet on the ratio, RNA $\times 10^{3}$ : protein. The ratios, protein:DNA and RNA:DNA were significantly lowered by the NF treatment and the MA groups showed intermediate values $(P<0.01)$.

The time-course changes in rates of release of radioactivity in $\mathrm{CO}_{2}$ are given in Fig. 1, showing that the plateau condition, on which the basis of the calculation of protein synthesis was made, was attained satisfactorily in the $8 \mathrm{~h}$ period when the SCG and MA diets were given, but not when the chicks were given the NF diet, since the radioactivity in the expired $\mathrm{CO}_{2}$ of this group increased linearly until the end of infusion. It was, however, clearly shown that there was a large reduction in expired $\mathrm{CO}_{2}$ on feeding the NF diet, and feeding the MA diet reduced it even further.

The values for $R$, relative pool size of phenylalanine (protein-bound/intracellular free), were not significantly different between any two means (GF-SCG 205, GF-NF 210, GF-MA 236, CV-SCG 211, CV-NF 214, CV-MA 176), and these values were used for calculations of breast muscle protein synthesis according to the formula described previously (p. 133). Table 3 shows the values for the FSR and protein synthesized. The FSR was reduced by feeding the NF diet and the reduction was partially but not significantly alleviated by supplementation with methionine and arginine. No difference in FSR was found between the GF and CV chicks. There was a tendency for a reverse effect, with a higher FSR on the NF diet and a lower FSR on the MA diet in the CV chicks compared with those of their GF counterparts. Essentially similar results to those found for the FSR were observed in the amount of protein synthesized expressed either in $\mathrm{mg} / \mathrm{d}$ or per unit RNA and DNA, which were reduced drastically by feeding the NF diet and the reduction was partially, though not significantly, alleviated by the MA diet with no difference between the GF and CV chicks. In the absolute amount of protein synthesized expressed in $\mathrm{mg} / \mathrm{d}$ and per unit DNA there were significant $(P<0.05)$ interactions between environment $x$ diet, caused by the higher values of the CV chicks given the NF diet compared with those of their GF counterparts, whereas the opposite was the case in the MA diet.

\section{Expts 2 and 3. Large-dose injection experiments}

The body-weight, muscle wet weight and the muscle protein, RNA and DNA contents are given in Table 4. In Expt 2, protein starvation by feeding the NF diet reduced body-weight, muscle weight, and muscle protein and RNA contents while the muscle DNA remained unchanged. No significant environmental effect was found in any of the measurements. In Expt 3 where the effect of supplementing the NF diet with methionine and arginine was 


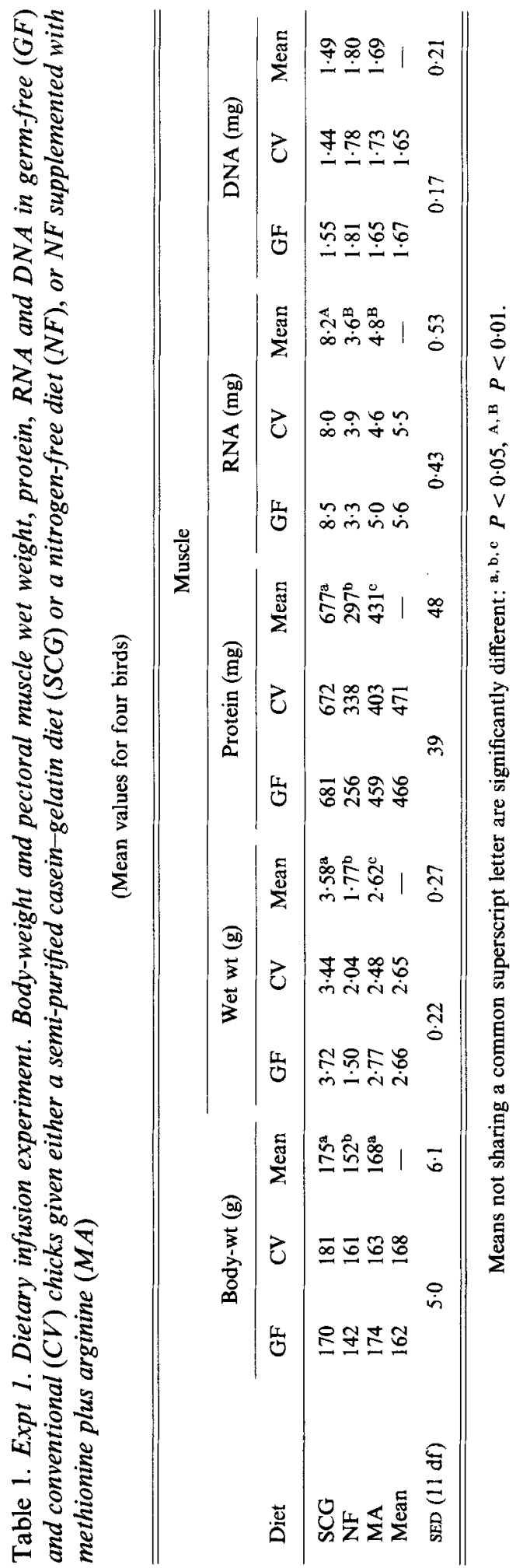


Table 2. Expt 1. Dietary infusion experiment. RNA:protein, protein:DNA and RNA:DNA in the pectoral muscle of germ-free $(G F)$ and conventional $(C V)$ chicks given either a semi-purified casein-gelatin diet $(S C G)$ or a nitrogen-free diet $(N F)$, or NF supplemented with methionine and arginine $(M A)$

(Mean values for four birds)

\begin{tabular}{|c|c|c|c|c|c|c|c|c|c|}
\hline \multirow[b]{2}{*}{ Diet } & \multicolumn{3}{|c|}{$\begin{array}{l}\text { Muscle RNA }\left(\times 10^{3}\right) \text { :protein } \\
(\mathrm{mg} / \mathrm{g})\end{array}$} & \multicolumn{3}{|c|}{$\begin{array}{l}\text { Muscle protein: DNA } \\
(\mathrm{mg} / \mathrm{mg})\end{array}$} & \multicolumn{3}{|c|}{$\begin{array}{l}\text { Muscle RNA:DNA } \\
(\mathrm{mg} / \mathrm{mg})\end{array}$} \\
\hline & GF & $\mathrm{CV}$ & Mean & GF & $\mathrm{CV}$ & Mean & GF & $\mathrm{CV}$ & Mean \\
\hline SCG & $12 \cdot 8$ & 11.9 & $12 \cdot 3$ & 447 & 475 & $461^{A}$ & 5.69 & $5 \cdot 61$ & $5 \cdot 65^{a}$ \\
\hline NF & $13 \cdot 2$ & 13.7 & 13.5 & 148 & 182 & $165^{\mathrm{B}}$ & 1.96 & $2 \cdot 16$ & $2 \cdot 06^{\mathrm{b}}$ \\
\hline MA & $10 \cdot 7$ & $11 \cdot 6$ & $11 \cdot 1$ & 288 & 238 & $263^{C}$ & 3.05 & 2.67 & $2 \cdot 86^{\mathrm{c}}$ \\
\hline Mean & $12 \cdot 2$ & 12.4 & - & 294 & 298 & - & $3 \cdot 57$ & $3 \cdot 48$ & - \\
\hline $\operatorname{SED}(11 \mathrm{df})$ & \multicolumn{2}{|c|}{$1 \cdot 1$} & $1 \cdot 3$ & \multicolumn{2}{|c|}{25} & 30 & \multicolumn{2}{|c|}{0.24} & 0.29 \\
\hline
\end{tabular}

Means not sharing a common superscript letter are significantly different: a, b, c $P<0.05$, A B, C $P<0.01$.

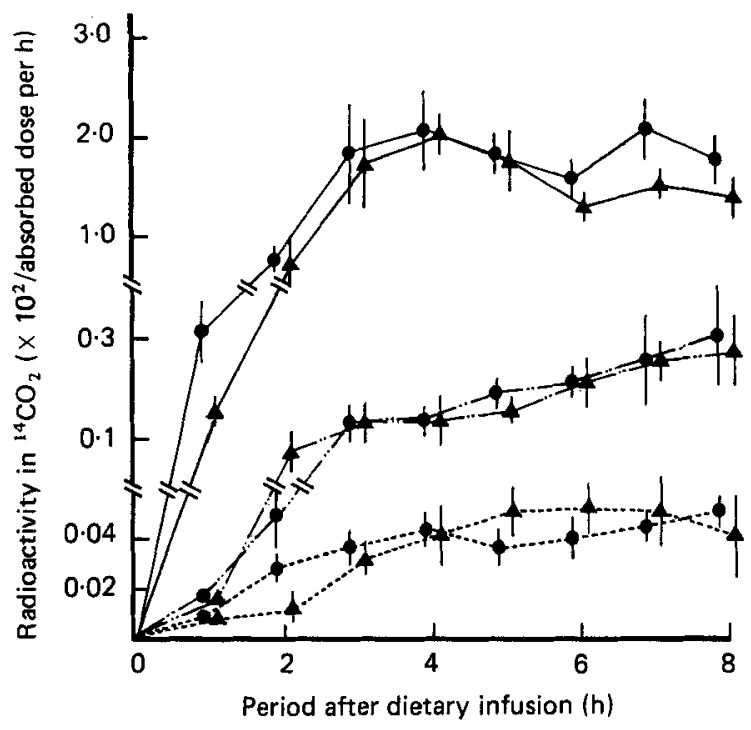

Fig. 1. Expt 1. Time-course changes in radioactivity of expired carbon dioxide in germ-free $(-)$ and conventional $(\boldsymbol{\Delta})$ chicks given a semi-purified casein-gelatin diet $(-)$, or a nitrogen-free diet $(-\cdots-; \mathbf{N F})$, or NF supplemented with methionine and arginine (---) during an $8 \mathrm{~h}$ dietary infusion of [U${ }^{14} \mathrm{C}$ lphenylalanine. Points are mean values with their standard errors represented by vertical bars for four birds.

tested, body-weight and muscle weight were heavier in the birds given the MA diet than in those given the NF diet with no difference between environments. The muscle protein and RNA contents were higher in the MA group than in the NF group, while no change was found in the muscle DNA contents. Throughout the measurements, no environmental effect nor its interaction with diet was detected.

The ratios, muscle RNA:protein, protein:DNA and RNA:DNA are shown in Table 5. After protein starvation (Expt 2), all the ratios were reduced, to the greatest extent in 


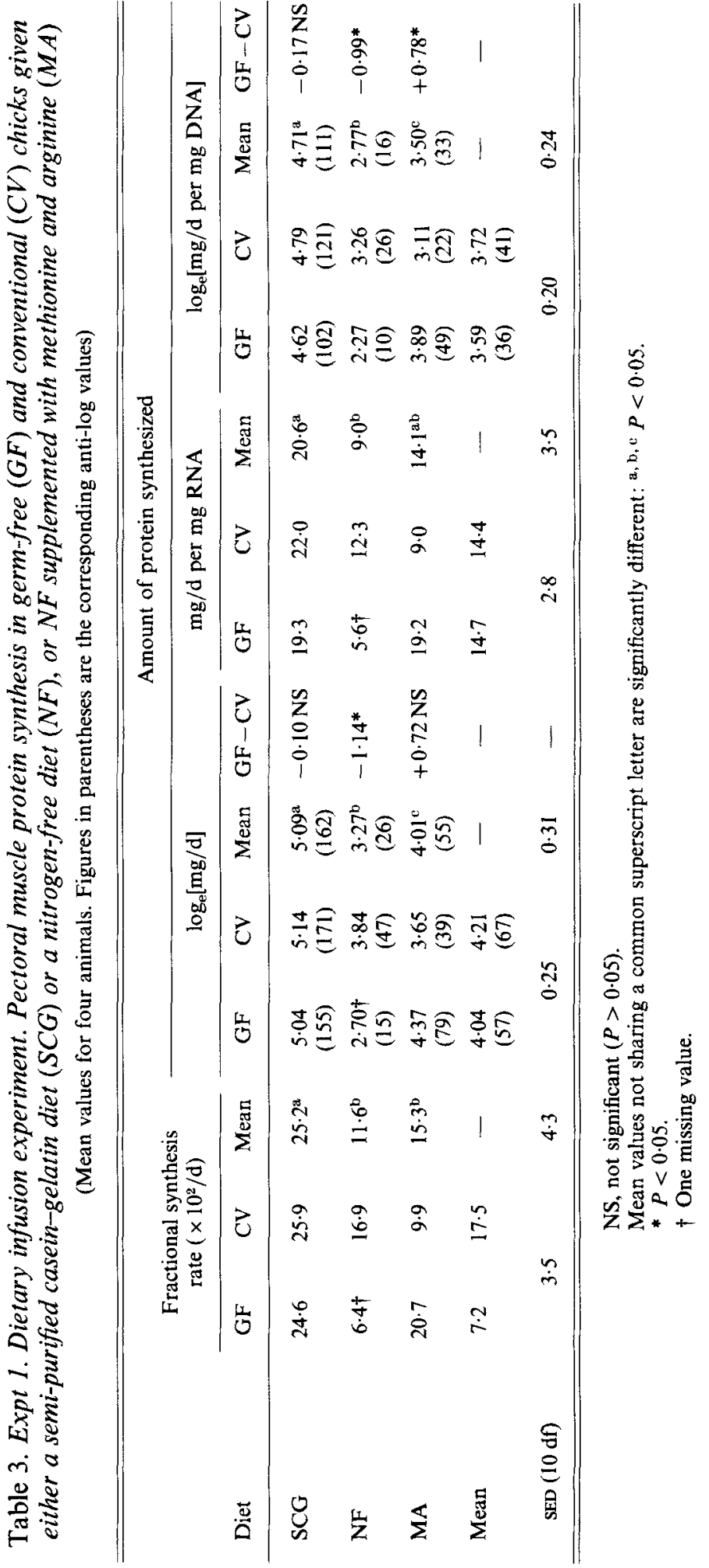


Muscle protein turnover in germ-free chicks

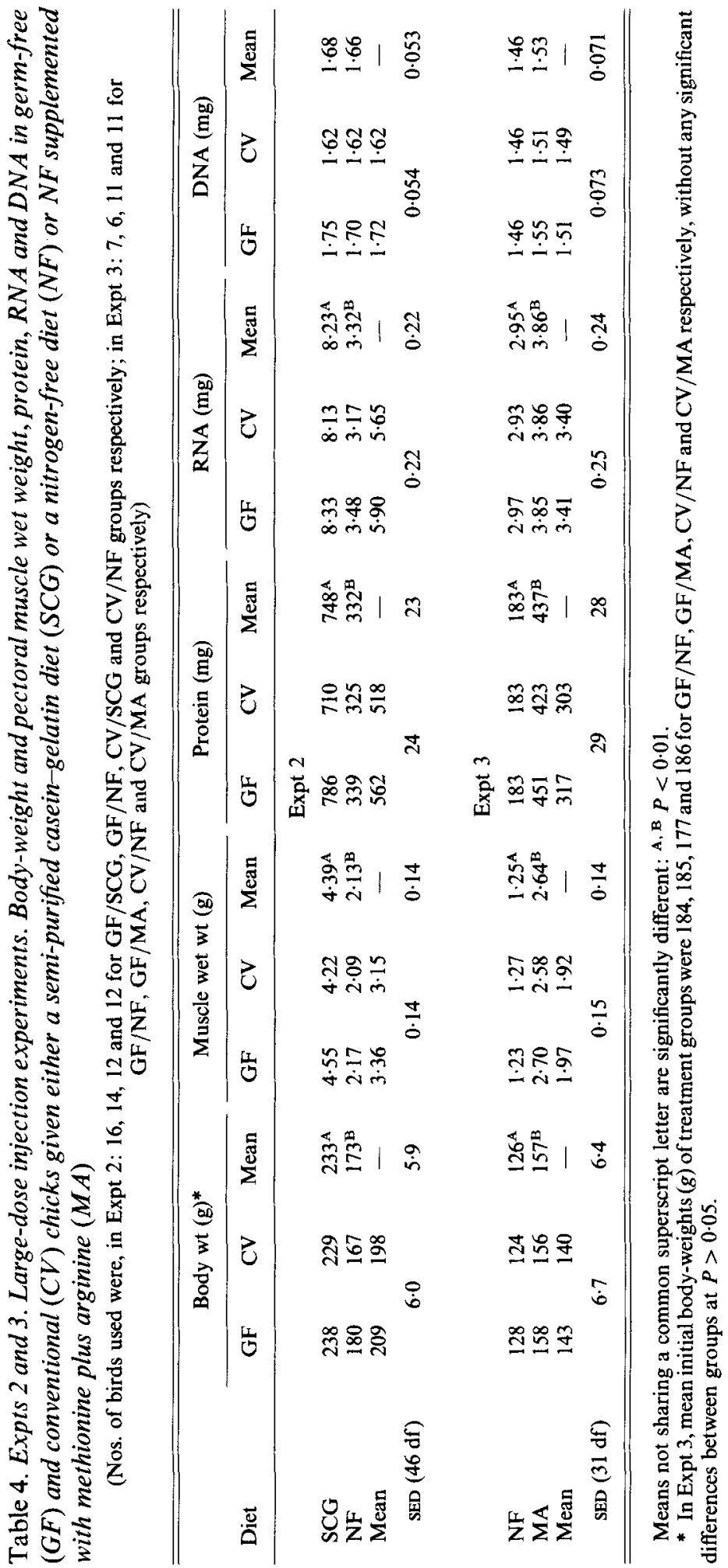


Table 5. Expts 2 and 3. Large-dose injection experiments. The ratios, $R N A$ : protein, protein: $D N A$, and RNA:DNA in the pectoral muscle of germ-free $(G F)$ and conventional $(C V)$ chicks given either a semi-purified casein-gelatin diet $(S C G)$ or a nitrogen-free diet $(N F)$, or $N F$ supplemented with methionine and arginine $(M A)$

(Nos. of birds used were, in Expt 2: 16, 14, 12 and 12 for GF/SCG, GF/NF, CV/SCG and CV/NF groups respectively; in Expt 3: 7, 6, 11 and 11 for GF/NF, GF/MA, CV/NF and CV/MA groups respectively)

\begin{tabular}{|c|c|c|c|c|c|c|c|c|c|c|}
\hline \multirow[b]{2}{*}{ Diet } & \multicolumn{4}{|c|}{ RNA $\times 10^{3}:$ protein $(\mathrm{mg} / \mathrm{g})$} & \multicolumn{3}{|c|}{ Protein: DNA $(\mathrm{mg} / \mathrm{mg})$} & \multicolumn{3}{|c|}{ RNA : DNA (mg/mg) } \\
\hline & GF & $\mathrm{CV}$ & Mean & $\mathrm{GF}-\mathrm{CV}$ & GF & $\mathrm{CV}$ & Mean & GF & $\mathrm{CV}$ & Mean \\
\hline \multicolumn{11}{|c|}{ Expt 2} \\
\hline SCG & $10 \cdot 6$ & $11 \cdot 5$ & $11 \cdot 1^{\mathrm{A}}$ & $-0.9^{*}$ & 455 & 441 & $448^{\mathrm{A}}$ & $4 \cdot 82$ & 5.04 & $4.93^{\mathrm{A}}$ \\
\hline $\mathrm{NF}$ & $10 \cdot 4$ & $9 \cdot 8$ & $10 \cdot 1^{\mathrm{B}}$ & $+0.6 \mathrm{NS}$ & 200 & 202 & $201^{B}$ & $2 \cdot 05$ & 1.97 & $2 \cdot 01^{\mathrm{B}}$ \\
\hline Mean & $10 \cdot 5$ & $10 \cdot 7$ & - & - & 327 & 321 & - & $3 \cdot 44$ & $3 \cdot 51$ & - \\
\hline SED $(46 \mathrm{df})$ & \multicolumn{2}{|c|}{0.27} & $0 \cdot 26$ & $0 \cdot 38$ & \multicolumn{2}{|c|}{$14 \cdot 2$} & $14 \cdot 1$ & \multicolumn{2}{|c|}{$0 \cdot 14$} & $0 \cdot 13$ \\
\hline \multicolumn{11}{|c|}{ Expt 3} \\
\hline NF & 16.5 & $16 \cdot 1$ & $16 \cdot 3^{\mathrm{A}}$ & & 126 & 124 & $125^{\mathrm{A}}$ & 2.05 & 1.95 & $2 \cdot 00^{\mathrm{a}}$ \\
\hline MA & $9 \cdot 2$ & $9 \cdot 1$ & $9 \cdot 1^{\mathrm{B}}$ & & 280 & 282 & $281^{\mathrm{B}}$ & $2 \cdot 48$ & $2 \cdot 55$ & $2 \cdot 52^{b}$ \\
\hline Mean & $12 \cdot 9$ & $12 \cdot 6$ & - & & 203 & 203 & - & $2 \cdot 26$ & $2 \cdot 25$ & - \\
\hline SED (31 df) & & & 0.97 & 0.94 & & & $16 \cdot 9$ & & & $0 \cdot 14$ \\
\hline
\end{tabular}

NS, not significant $(P>0.05),{ }^{*} P<0.05$.

Means not sharing a common superscript letter are significantly different: ${ }^{\mathrm{a}, \mathrm{b}} P<0.01,{ }^{\mathrm{A}, \mathrm{B}} P<0.001$.

Table 6. Expts 2 and 3. Large-dose injection experiments. Pectoral muscle protein turnover rates in germ-free $(G F)$ and conventional $(C V)$ chicks given either a semi-purified casein-gelatin diet $(S C G)$ or a nitrogen-free diet $(N F)$, or $N F$ supplemented with methionine plus arginine $(M A)$

(Nos. of birds used were, in Expt 2: 7, 7,5 and 6 for GF/SCG, GF/NF, CV/SCG and CV/NF groups respectively; in Expt 3: 4, 3, 6 and 6 for GF/NF, GF/MA, CV/NF and CV/MA groups respectively. Figures in parentheses are the corresponding anti-log values)

\begin{tabular}{|c|c|c|c|c|c|c|c|c|c|c|c|c|}
\hline \multirow[b]{3}{*}{ Diet } & \multicolumn{6}{|c|}{ Synthesis } & \multicolumn{6}{|c|}{ Degradation } \\
\hline & \multicolumn{3}{|c|}{$\begin{array}{l}\text { Fractional rate } \\
\qquad\left(\times 10^{2} / \mathrm{d}\right)\end{array}$} & \multicolumn{3}{|c|}{$\begin{array}{l}\text { Absolute rate } \\
\left(\log _{\mathrm{e}}[\mathrm{mg} / \mathrm{d}]\right)\end{array}$} & \multicolumn{3}{|c|}{$\begin{array}{l}\text { Fractional rate } \\
\qquad\left(\times 10^{2} / \mathrm{d}\right)\end{array}$} & \multicolumn{3}{|c|}{$\begin{array}{l}\text { Absolute rate } \\
(\mathrm{mg} / \mathrm{d})\end{array}$} \\
\hline & $\mathrm{GF}$ & $\mathrm{CV}$ & Mean & GF & $\mathrm{CV}$ & Mean & GF & $\mathrm{CV}$ & Mean & $\mathrm{GF}$ & CV & Mean \\
\hline \multicolumn{13}{|c|}{ Expt 2} \\
\hline SCG & $17 \cdot 6$ & $18 \cdot 7$ & $18 \cdot 2^{\mathrm{A}}$ & $\begin{array}{l}4.92 \\
(136)\end{array}$ & $\begin{array}{r}4.90 \\
(134)\end{array}$ & $\begin{array}{l}4.91^{A} \\
(135)\end{array}$ & $9 \cdot 5$ & $10 \cdot 6$ & $10 \cdot 1^{a}$ & $87 \cdot 3+$ & $80 \cdot 9$ & $84 \cdot 1^{\mathrm{a}}$ \\
\hline NF & $5 \cdot 3$ & $7 \cdot 1$ & $6 \cdot 2^{\mathrm{B}}$ & $\begin{array}{l}2.82 \\
(17)\end{array}$ & $\begin{array}{l}3 \cdot 09 \\
(22)\end{array}$ & $\begin{array}{l}2.95^{\mathrm{B}} \\
(19)\end{array}$ & $14 \cdot 4$ & $15 \cdot 8$ & $15 \cdot 1^{b}$ & $49 \cdot 2$ & $49 \cdot 6$ & $49 \cdot 4^{b}$ \\
\hline Mean & $11 \cdot 5$ & $12 \cdot 1$ & - & $\begin{array}{l}3 \cdot 87 \\
(48)\end{array}$ & $\begin{array}{l}3.99 \\
(54)\end{array}$ & - & $12 \cdot 0$ & $13 \cdot 2$ & - & $68 \cdot 2$ & $65 \cdot 2$ & - \\
\hline $\operatorname{SED}(17 \mathrm{df})$ & \multicolumn{2}{|c|}{1.81} & $1 \cdot 80$ & \multicolumn{2}{|c|}{$0 \cdot 20$} & $0 \cdot 19$ & \multicolumn{2}{|c|}{$1 \cdot 84$} & $1 \cdot 83$ & \multicolumn{2}{|c|}{$14 \cdot 2$} & $14 \cdot 2$ \\
\hline \multicolumn{13}{|c|}{ Expt 3} \\
\hline NF & $12 \cdot 2$ & $10 \cdot 6$ & $11 \cdot 4^{\mathrm{a}}$ & $25 \cdot 1$ & $21 \cdot 7$ & $23 \cdot 4^{\mathrm{A}}$ & $25 \cdot 2$ & $24 \cdot 7$ & $25 \cdot 0^{\mathrm{A}}$ & $49 \cdot 3$ & $48 \cdot 4$ & $48 \cdot 9^{A}$ \\
\hline MA & $13 \cdot 8$ & $14 \cdot 2$ & $14 \cdot 0^{\mathrm{b}}$ & $69 \cdot 3$ & $68 \cdot 6$ & $68 \cdot 9^{B}$ & 15.9 & $17 \cdot 2$ & $16 \cdot 6^{\mathrm{B}}$ & $79 \cdot 5$ & $83 \cdot 0$ & $81 \cdot 3^{B}$ \\
\hline Mean & $13 \cdot 0$ & $12 \cdot 4$ & - & $47 \cdot 2$ & $45 \cdot 1$ & - & $20 \cdot 6$ & $21 \cdot 0$ & -- & $64 \cdot 4$ & 65.7 & - \\
\hline SED (15 df) & \multicolumn{2}{|c|}{1.01} & 0.97 & \multicolumn{2}{|c|}{$6 \cdot 12$} & 5.91 & \multicolumn{2}{|c|}{$1 \cdot 87$} & $1 \cdot 81$ & \multicolumn{2}{|c|}{5.78} & 5.59 \\
\hline
\end{tabular}

Means not sharing a common superscript letter are significantly different: ${ }^{\mathrm{a}, \mathrm{b}} P<0.05, \mathrm{~A}, \mathrm{~B} P<0.001$. $\dagger$ One missing value. 
Table 7. Expts 2 and 3. Large-dose injection experiments. The amounts of protein synthesized per unit RNA and DNA in breast muscle of germ-free $(G F)$ and conventional $(C V)$ chicks given either a semi-purified casein-gelatin diet $(S C G)$ or a nitrogen-free diet $(N F)$, or NF supplemented with methionine plus arginine $(M A)$

(Nos. of birds used were, in Expt 2: 7, 7,5 and 6 for GF/SCG, GF/NF, CV/SCG and CV/NF groups respectively; in Expt 3: 4, 3,6 and 6 for GF/NF, GF/MA, CV/NF and CV/MA groups respectively.

Figures in parentheses are the corresponding anti-log values)

\begin{tabular}{|c|c|c|c|c|c|c|}
\hline \multirow[b]{2}{*}{ Diet } & \multicolumn{3}{|c|}{$\mathrm{mg} / \mathrm{d}$ per mg RNA } & \multicolumn{3}{|c|}{$\log _{e}[\mathrm{mg} / \mathrm{d}$ per mg DNA $]$} \\
\hline & GF & $\mathrm{CV}$ & Mean & GF & $\mathrm{CV}$ & Mean \\
\hline \multicolumn{7}{|c|}{ Expt 2} \\
\hline SCG & $16 \cdot 7$ & $16 \cdot 2$ & $16 \cdot 4^{A}$ & $\begin{array}{l}4 \cdot 32 \\
(75)\end{array}$ & $\begin{array}{l}4.39 \\
(81)\end{array}$ & $\begin{array}{l}4 \cdot 36^{A} \\
(78)\end{array}$ \\
\hline NF & 4.9 & $7 \cdot 0$ & $6 \cdot 0^{\mathrm{B}}$ & $\begin{array}{l}2 \cdot 26 \\
(10)\end{array}$ & $\begin{array}{l}2.61 \\
\text { (14) }\end{array}$ & $\begin{array}{l}2 \cdot 44^{\mathrm{B}} \\
(11)\end{array}$ \\
\hline Mean & $10 \cdot 8$ & $11 \cdot 6$ & - & $\begin{array}{l}3 \cdot 29 \\
(27)\end{array}$ & $\begin{array}{l}3.50 \\
(33)\end{array}$ & - \\
\hline \multirow[t]{3}{*}{$\operatorname{SED}(17 \mathrm{df})$} & \multicolumn{2}{|c|}{1.89} & 1.86 & \multicolumn{2}{|c|}{$0 \cdot 175$} & $0 \cdot 172$ \\
\hline & & & & \multicolumn{3}{|c|}{$\mathrm{mg} / \mathrm{d}$ per mg DNA } \\
\hline & \multicolumn{3}{|c|}{ Expt 3} & GF & $\mathrm{CV}$ & Mean \\
\hline NF & 7.8 & 6.7 & $7 \cdot 3^{\mathrm{A}}$ & 17.5 & $13 \cdot 3$ & $15 \cdot 4^{\mathrm{A}}$ \\
\hline MA & 17.8 & $16 \cdot 1$ & $17 \cdot 0^{\mathrm{B}}$ & $41 \cdot 8$ & 43.7 & $42 \cdot 7^{\mathrm{B}}$ \\
\hline Mean & $12 \cdot 8$ & $11 \cdot 4$ & - & $29 \cdot 7$ & $28 \cdot 5$ & - \\
\hline $\operatorname{SED}(15 \mathrm{df})$ & \multicolumn{2}{|c|}{1.55} & 1.50 & \multicolumn{2}{|c|}{4.77} & $4 \cdot 61$ \\
\hline
\end{tabular}

Means not sharing a common superscript letter are significantly different: ${ }^{A}, \mathbf{B} P<0.001$.

RNA:DNA, followed by protein:DNA and RNA:protein. Since there were no changes in the DNA content (Table 4), the reductions in these values were mainly the results of the alterations in RNA and protein, particularly in the former. A significant interaction between environment $\times$ diet was found in RNA:protein $(P<0.01)$, for which a greater reduction in the CV birds on protein starvation seemed responsible. By supplementing the NF diet with methionine and arginine in Expt 3, the RNA:protein value was significantly reduced $(P<0.001)$ but those of protein:DNA and RNA:DNA were increased at $P<0.001$ and $P<0.01$ respectively. No significant effect was observed between the GF and CV environments on any of these measurements. Since by supplementing the NF with methionine and arginine the DNA content was not altered, the changes observed were attributed to those found in protein and RNA.

Table 6 gives the values for muscle protein synthesis and degradation in fractional and absolute rates. After protein starvation by feeding the NF diet (Expt 2), the FSR was reduced to about one-third, whereas the FDR was increased. When the absolute amount was calculated, both synthesis and degradation rates of the pectoral muscle protein were lowered by protein starvation, the extent of the reduction in the former being larger. By supplementing the NF diet with methionine and arginine (Expt 3), the FSR was increased and the FDR decreased with no differences between the GF and CV states. When these values were expressed in absolute terms, protein synthesis and degradation rates were accelerated in the birds given the MA diet compared with the NF diet. Again, in these 
absolute rates the GF values were not significantly different from those of their $\mathrm{CV}$ controls. Throughout the indices measured in Expts 2 and 3, where the large-dose injection technique was used, no interaction between environment $x$ diet was detected in protein turnover rates in the pectoral muscle.

Amounts of protein synthesized per unit RNA and DNA, given in Table 7, showed a reduction on feeding the NF diet but no significant differences between environments (Expt 2). By supplementing the NF diet with methionine and arginine these values were significantly increased $(P<0.001)$ with no differences between environments.

\section{DISCUSSION}

In the present study, breast muscle protein turnover was measured in GF and CV chicks after protein starvation with or without methionine and arginine supplements using two methods: the dietary-infusion and large-dose injection of labelled amino acids. Because of the limitation in numbers of birds that could be accommodated at any one time, the effects of protein deprivation by feeding the NF diet and of supplementing with methionine and arginine were investigated in separate studies in Britain and Japan with birds of different breeds and body-weights. Although these differences could have had some influence on the actual values obtained for breast muscle protein turnover rates, our main interest was in the dietary and environmental effects, which could be compared and evaluated within each study.

Harney et al. (1976) and Maruyama et al. (1978) reported that dietary infusion of labelled amino acid produced isotope equilibrium in plasma and muscle, as evidenced by a plateau in the radioactivity of the expired $\mathrm{CO}_{2}$, within $6 \mathrm{~h}$. After following a similar dietary infusion procedure for a longer period of $8 \mathrm{~h}$, the proportion of phenylalanine oxidized, as shown in Fig. 1, was considerably reduced on feeding the NF diet, suggesting that there was an adaptation of birds to protein depletion in order to save $\mathrm{N}$ loss, as found in rats (McFarlane $\&$ von Holt, 1969; Reeds, 1974) and implied by studies in rats and chicks on changes in activities of enzymes involved in amino acid catabolism (Schimke, 1962; Scholz \& Featherston, 1969). The reduced proportion of amino acid oxidized when the NF diet was given was further decreased by supplementing the NF diet with methionine and arginine. It may be that addition of these amino acids diverted a proportion of the amino acid flux towards synthesis through improved reutilization of amino acids formed endogenously from body protein catabolism.

Judging by the shape of the $\mathrm{CO}_{2} v$. time curve, however, isotopic equilibrium was not reached by the end of infusion in the chicks given the NF diet despite a longer dietary infusion period of $8 \mathrm{~h}$. This would have brought about a serious distortion in the subsequent calculation of the breast muscle protein synthesis in the birds given the NF diet, and also casts a doubt on the validity of the dietary-infusion method for the measurement of protein synthesis in tissues, particularly when a poor dietary regimen is to be used. Furthermore, in Expt 1, the assay of phenylalanine could have measured other metabolites including tyrosine that would have become labelled after the $8 \mathrm{~h}$ administration of labelled phenylalanine via the diet. Accordingly, it was considered that the measurement of protein turnover rates obtained by the large-dose injection method (Expts 2 and 3) would be more reliable than those by the dietary-infusion method (Expt 1). Advantages of the use of the large-dose injection method have been described elsewhere (Garlick et al. 1980).

Nevertheless some results on the breast muscle protein synthesis and the related measurements using the dietary-infusion technique were roughly in agreement with those obtained by the large-dose injection of labelled phenylalanine; in general the presence of the gut microflora had little, if any, effect on protein synthesis rates in chick breast muscle, 
while it was reduced after feeding the NF diet, and the reduction was partially alleviated by methionine and arginine supplementation. There was an interaction between environment $x$ diet, not always significant, mainly caused by low values of GF/NF and CV/MA groups in FSR and amounts of protein synthesized (Table 3). However, these differences seem more likely to stem from a methodological problem rather than being a reflection of true treatment effects since delivery of radioisotope to the site of protein synthesis by the dietary-infusion method was crucially dependent on appetite throughout the infusion period. The birds belonging to GF/NF and CV/MA groups may have eaten a considerable proportion of their diets towards the end of the $8 \mathrm{~h}$ infusion period, leading to high specific radioactivity in plasma and intracellular free pool, and hence low FSR values. Therefore, irregular food intake could be one of the possible reasons for the anomalies observed in breast muscle protein synthesis by the dietary-infusion technique.

Protein starvation lowered FSR and increased FDR of the chick breast muscle as shown by the results obtained by the large-dose injection method (Table 6). In the case of young chick breast muscle the protein mass, therefore, appears to be regulated both through decrease in protein synthesis and increase in degradation rate. In rats, muscle protein mass on protein starvation is apparently regulated primarily by alterations in protein synthesis with changes in degradation rate in the same direction (Garlick et al. 1975; Millward et al. 1976). When the changes in muscle protein turnover of chicks were compared in terms of absolute amounts, a large reduction in synthesis with a small reduction in degradation were observed, suggesting that changes in protein synthesis are of primary importance in the regulation of chick breast muscle mass. MacDonald \& Swick (1981) also reached the same conclusion in protein-depleted and protein-repleted chicks at 2-7 weeks of age. However, Maruyama et al. (1978) considered that degradation rate was a more important regulator of muscle protein balance than synthesis rate in chicks up to 2 weeks of age. It may be that the mechanisms controlling protein balance are influenced by the age and nutritional status of the birds.

The ratio, RNA:protein was unchanged either by dietary treatment or by environment, except for those given the MA diet in Expt 3, implying that protein was generally lost at the same rate as RNA. In contrast, protein synthesis per unit RNA, an index of the efficiency of translation, was reduced by protein starvation and the reduction was partly alleviated by supplementing with methionine and arginine. Reduced protein synthesis per unit RNA, therefore, would almost account for the reduction in breast muscle FSR and amount of protein synthesized in chicks given the NF diet. This is in accordance with the fact that a reduced proportion of polyribosome to the total ribosome content was brought about by protein depletion (Young \& Alexis, 1968; Young et al. 1968). The partial restoration of FSR by supplementing with methionine and arginine would also be accompanied by changes in the proportion of polyribosome to the total ribosome content, since an improved proportion by supplementing the NF diet with methionine was reported in rats (Yokogoshi \& Yoshida, 1980).

In liver or jejunal mucosa, which harbour or are in close association with micro-organisms in $\mathrm{CV}$ life, the presence of the gut microflora enhanced, though not significantly, protein synthesis (Muramatsu et al. 1983). In contrast, skeletal muscle is more remote from the sites colonized by micro-organisms, and therefore a direct effect of the gut bacteria on muscle protein turnover would be less likely. Nevertheless, there could be an indirect effect due to changes in overall growth. It is well known that GF birds grow better than their CV controls when given an adequate diet (Coates et al. 1963) while, on protein starvation, better $\mathrm{N}$ retention by CV birds has been reported (Okumura et al. 1978). However, the present results established little or no effect of microflora. It may be that the observed change in growth between environments was so small that it was not reflected in alterations in the 
breast muscle protein growth, and hence in its protein turnover, or that the particular breast muscle used in the present study was not a good representative of the whole body in chicks.

The specific breast muscle, $M$. pectoralis profundus, was used in the present work because: (a) it was relatively easy to dissect out the entire preparation, (b) unlike leg muscles, the breast muscle is less influenced by continual activity and stretching which may have a stimulating effect on muscle protein synthesis (Goldspink, 1977; Laurent et al. 1978).

It was shown in Expt 3 with the large-dose injection technique that supplementing with methionine and arginine considerably enhanced the FSR and absolute amounts of protein synthesized of the chick breast muscle compared with those of the unsupplemented NF diet. This substantial enhancement of protein synthesis in breast muscle was expected because Muramatsu \& Okumura $(1979 a, 1980)$ found an alleviation of loss in body-weight and $\mathrm{N}$ by supplementing with methionine and arginine. Even under the condition of protein starvation feathers, of which cystine and arginine contents are relatively higher than in other tissues (Mitchell, 1959), were still growing at this age (Muramatsu \& Okumura, 1979 b), implying increased needs for these amino acids. In protein-depleted birds it was probably skeletal muscle which supplied most amino acids, especially cystine and arginine, to support other metabolic events such as feather growth. This hypothesis was substantiated by the fact that skeletal muscle showed greatest alleviation of $\mathrm{N}$ loss on supplementation with methionine and arginine, almost entirely accounting for the total $\mathrm{N}$ spared in the whole body (Muramatsu \& Okumura, 1979 b). Thus, supplementary methionine and arginine would spare not only the $\mathrm{N}$ present in these amino acids but also $\mathrm{N}$ of other amino acids that are produced as a result of protein breakdown to provide the required amounts of sulphur-containing amino acids and arginine, thereby leading to an enhanced re-utilization of endogenously formed amino acids.

The FDR was reduced by supplementing with methionine and arginine (Table 6), although the reason for this is not obvious. Admittedly, in young chick breast muscle, changes in the FDR were in the opposite direction to those in the FSR as shown by supplementing with methionine and arginine (Table 6) and indicated by responses to protein starvation (Table 3). As discussed earlier, this may mean quite different regulatory mechanisms of muscle protein turnover in chicks and other animals. In rats, for example, the FDR of muscle protein frequently showed counter-productive changes in the same direction towards the FSR in response to a variety of dietary treatments (Garlick et al. 1975; Millward et al. 1976). Whether or not the observed changes in protein turnover rates in young chicks are characteristic of this specific breast muscle remains to be studied.

The authors are grateful to Mr J. P. Fordham for care of the birds, and to Mrs R. Anderson for her technical assistance, and are much indebted to Dr H. Yokota and Dr M. Furuse who co-operated in carrying out the germ-free experiment at the Nagoya University, Japan. Financial support was provided by the Ishizaka Foundation and a grant-in-aid (no. 548068) for Scientific Research from the Ministry of Education, Japan.

\section{REFERENCES}

Coates, M. E., Fuller, R., Harrison, G. F., Lev, M. \& Suffolk S. F. (1963). British Journal of Nutrition 17, $141-150$. Featherston, W. R. \& Horn, G. W. (1973). Journal of Nutrition 103, 757-765.

Fowler, V. R. (1980). In Growth in Animals, pp. 249-263. [T. L. J. Lawrence, editor]. London: Butterworths. Fuller, R. (1968). In The Germ-free Animal in Research, pp, 37-45 [M. E. Coates, editor]. London: Academic Press. Garlick, P. J., Burk, T. L. \& Swick, R. W. (1976). American Journal of Physiology 230, 1108-1112.

Garlick, P. J., Fern, M. \& Preedy, V. R. (1983). Biochemical Journal 210, 669-676.

Garlick, P. J., McNurlan, M. A. \& Preedy, V. R. (1980). Biochemical Journal 92, 719-723.

Garlick, P. J., Millward, D. J. \& James, W. P. T. (1973). Biochemical Journal 136, 935-945.

Garlick, P. J., Millward, D. J., James, W. P. T. \& Waterlow, J. C. (1975). Biochimica et Biophysica Acta 414, 71-84. 
Giles, K. W. \& Myers, A. (1965). Nature 206, 93.

Goldberg, A. L. \& Chang, T. W. (1978). Federation Proceedings 37, 2301-2307.

Goldspink, D. F. (1977). Journal of Physiology 264, 283-296.

Harney, M. E., Swick, R. W. \& Benevenga, N. J. (1976). American Journal of Physiology 231, 1018-1023.

Laurent, G. J., Sparrow, M. P. \& Millward, D. J. (1978). Biochemical Journal 176, 407-417.

Lowry, O. H., Rosebrough, N. J., Farr, A. L. \& Randall, R. J. (1951). Journal of Biological Chemistry 193, 265-275.

McCaman, M. W. \& Robins, E. (1962). Journal of Laboratory and Clinical Medicine 59, 885-890.

MacDonald, M. L. \& Swick, R. W. (1981). Biochemical Journal 194, 811-819.

McFarlane, I. G. \& von Holt, C. (1969). Biochemical Journal 111, 557-563.

McNurlan, M. A., Tomkins, A. M. \& Garlick, P. J. (1979). Biochemical Journal 178, 373-379.

Maruyama, K., Sunde, M. L. \& Swick, R. W. (1978). Biochemical Journal 176, 573-582.

Millward, D. J., Garlic, P. J., Nnanyelugo, D. O. \& Waterlow, J. C. (1976). Biochemical Journal 156, $185-188$.

Millward, D. J. \& Waterlow, J. C. (1978). Federation Proceedings 37, 2283-2290.

Mitchell, H. H. (1959). In Protein and Amino Acid Nutrition, pp. 11-43 [A. A. Albanese, editor]. New York: Academic Press.

Munro, H. N. \& Fleck, A. (1969. In Mammalian Protein Metabolism, vol. 3, pp. 443-525 [H. N. Munro, editor]. New York and London: Academic Press.

Muramatsu, T., Coates, M. E., Hewitt, D., Salter, D. N. \& Garlick, P. J. (1983). British Journal of Nutrition 49 , 453-462.

Muramatsu, T. \& Okumura, J. (1979a). Nutrition Reports International 19, 335-342.

Muramatsu, T. \& Okumura, J. (1979b). Nutrition Reports International 20, 709-716.

Muramatsu, T. \& Okumura, J. (1980). Journal of Nutrition 110, 59-65.

Okumura, J., Hewitt, D. \& Coates, M. E. (1978). British Journal of Nutrition 39, 99-104.

Reeds, P. J. (1974). British Journal of Nutrition 31, 259-270.

Rolls, B. A., Turvey, A. \& Coates, M. E. (1978). British Journal of Nutrition 39, 91-98.

Schimke, R. T. (1962). Journal of Biological Chemistry 237, 1921-1924.

Scholz, R. W. \& Featherston, W. R. (1969). Journal of Nutrition 98, 193-201.

Yokogoshi, H. \& Yoshida, A. (1980). Journal of Nutrition 110, 375-382.

Young, V. R. \& Alexis, S. D. (1968). Journal of Nutrition 96, 255-262.

Young, V. R., Chen, S. C. \& MacDonald, J. (1968). Biochemical Journal 106, 913-919. 